\title{
EVALUATION OF THE QUALITY OF PARTICLEBOARD PANELS MANUFACTURED WITH WOOD FROM Sequoia sempervirens AND Pinus taeda
}

\author{
Setsuo Iwakiri ${ }^{1 *}$, Rosilani Trianoski ${ }^{1}$, Alexsandro Bayestorff da Cunha ${ }^{2}$, Vinicus Gomes de Castro ${ }^{1}$, Rafael Leite \\ Braz $^{1}$, Bárbara Talamini Villas-Bôas ${ }^{1}$, Felipe Luis Sanches ${ }^{1}$, Karine Ramos da Rosa Bellon ${ }^{1}$, Edson Pinheiro ${ }^{1}$ \\ *Autor para correspondência: setsuo@ufpr.br
}

\begin{abstract}
This work aimed to evaluate the physical and mechanical properties of particleboard panels manufactured with wood particles from Sequoia sempervirens and Pinus taeda and urea-formaldehyde resin (UF), using different mixing ratios of the two species, namely 100\%, 0\%, 75\%, 50\% and 25\% of sequoia particles. Properties evaluated included panel density and compaction ratio, water absorption and thickness swelling after 24 hours of immersion, internal bond and static bending (MOE and MOR). The low density of sequoia wood raised the compaction ratio of the panels and helped improve their mechanical properties and dimensional stability. Panels manufactured at the ratios of $100 \%, 75 \%, 50 \%$ and $25 \%$ sequoia to pine provided better results compared to panels manufactured with $100 \%$ pine. Results of MOE and MOR under static bending and of internal bond met the minimum requirements of standard EN 312:2003 in all treatments. Results revealed that Sequoia sempervirens has great potential for production of particleboard.
\end{abstract}

Keywords: wood particles, urea-formaldehyde resin, species mixing ratio.

\section{AVALIAÇÃo DA QUALIDADE DE PAINÉIS AGLOMERADOS PRODUZIDOS COM MADEIRA DE Sequoia sempervirens E Pinus taeda}

\begin{abstract}
RESUMO: O objetivo do presente trabalho foi avaliar as propriedades físicas e mecânicas de painéis aglomerados produzidos a partir de partículas de madeira de Sequoia sempervirens e Pinus taeda com resina uréia-formaldeido (UF) em diferentes proporções de mistura das duas espécies, sendo $100 \%, 0 \%, 75 \%, 50 \%$ e $25 \%$ de partículas de sequoia, respectivamente. Foram avaliadas as propriedades de massa específica e razão de compactação dos painéis, absorção de água e inchamento em espessura após 24 horas de imersão, ligação interna e flexão estática (MOE e MOR). A baixa massa específica da madeira de sequoia elevou a razão de compactação dos painéis e contribuiu para melhorar as suas propriedades mecânicas e estabilidade dimensional. Os painéis produzidos com sequoia nas proporções de $100 \%, 75 \%, 50 \%$ e $25 \%$ em mistura com pinus, apresentaram melhores resultados de propriedades em relação aos painéis produzidos com $100 \%$ de pinus. Os resultados de MOE e MOR em flexão estática e ligação interna de todos os tratamentos avaliados atenderam aos requisitos mínimos da norma EN 312:2003. Os resultados demonstram que a Sequoia sempervirens apresenta grande potencial para produção de painéis aglomerados.
\end{abstract}

Palavras-chave: partículas de madeira, resina ureia-formaldeído, mistura de espécies.

\section{INTRODUCTION}

Use of new, fast-growing wood species obtained in forest stands for particleboard production has been the focus of several studies in Brazil in recent decades. That is justified, given that Brazil's MDF and particleboard companies rely on pine and eucalyptus as the main sources of raw material, and there is a need to increase the supply of wood available with alternative species.

From the 1990s, the Brazilian sector of reconstituted wood panels has expanded considerably and has shown a significant increase in its production capacity, with introduction of new particleboard and MDF industrial units. The increase in panel production has boosted the

1 Universidade Federal do Paraná - Curitiba, Paraná, Brazil

2 Universidade do Estado de Santa Catarina - Lajes, Santa Catarina, Brazil demand for raw material, and so the forest sector has been looking for future alternatives capable of responding to limited supplies of pine and eucalyptus woods, quantitatively and qualitatively. With the technological innovations introduced particularly in the past decade, a significant improvement has been noted in the quality of particleboard panels, also known commercially as medium density particleboard - MDP (ASSOCIAÇÃO BRASILEIRA DA INDÚSTRIA DE PAINÉIS DE MADEIRA - ABIPA, 2012).

Several researchers have engaged in studies about alternative species to pine and eucalyptus woods for the manufacture of particleboard panels. Trianoski et al. (2011b) evaluated the potential of species Acrocarpus

Cerne, Lavras, v. 20, n. 2, p. 209-216, abr./jun. 2014 
fraxinifolius, Melia azedarach, Gravile arobusta, Schizolobium parahyba and Toona ciliata. Iwakiri et al. (2010) studied the behavior of Schizolobium amazonicum, a tropical species grown in forest stands of the Amazon region, for laboratory production of particleboards. All species studied by the above researchers showed great potential for production of particleboards. Iwakiri et al. (2010) evaluated the quality of wood in five species of tropical pine, namely Pinus oocarpa, Pinus caribaea, Pinus chiapensis, Pinus maximinoi and Pinus tecunumannii for production of particleboard panels, and the results of physico-mechanical properties did substantiate their potential, with Pinus moximinoi standing out from other species. Protásio et al. (2012) studied the effects of compaction ratio and bulk density in three eucalyptus species, namely Eucalyptus grandis, Eucalyptus saligna and Eucalyptus cloeziana, and found a direct correlation between these variables and the bending properties, but an inverse correlation with the thickness swelling of the resulting particleboard panels.

Sequoia sempervirens is a species native to the United States whose characteristics include low-density wood (about $310 \mathrm{~kg} \cdot \mathrm{m}^{-3}$ ), good dimensional stability and resistance to decay, besides having excellent attributes for production of panels and cellulose pulp (MARCHIORI, 1996 cited by DIEL; FRIZZO, 2002; SLOAN; BOE, 1974). Spichiger (2004) points to several characteristics that make sequoia wood attractive for panel production and furniture making, including good workability, good adhesion for paints and varnishes and absence of resins that are typical of softwoods. Depending on surface quality, number of knots and sapwood, sequoia wood is an excellent choice for obtaining high value-added products, on account of its color and price. In Brazil, experimental sequoia stands are currently being tried in Santa Catarina state.

Maloney (1993) and Moslemi (1974) cited wood density, $\mathrm{pH}$ and extractives as critical parameters when selecting wood species to produce particleboard panels. Measuring wood density is a basic requirement when selecting species intended for particleboards, given that it influences the compaction ratio of the resulting panel. According to Moslemi (1974), compaction ratio is the ratio of panel density to wood density, noting that it should be at least 1.3 in order to ensure enough densification for panel formation to occur. Kelly (1977) states that, for panels with the same density, those made with low-density wood will have superior mechanical properties but inferior dimensional stability compared to panels made with high- density wood. The author attributes this behavior to the larger quantity of wood particles and resulting increase in hygroscopic swelling, and greater compressive stress being released during the hot-press process.

According to Iwakiri et al. (1996), mixing different species in the manufacture of particleboards is highly desirable in that it expands the offer of raw material to manufacturers that in turn require large volumes of wood. The differing physicochemical characteristics of the species involved can be offset by uniformly blending the wood particles so as to facilitate bonding and panel formation.

Fully or partially using new species to produce particleboards is a viable and sustainable alternative while contributing to improve the quality and the properties of the resulting panels. Experimental stands of species Sequoia sempervirens have been showing great potential for silviculture, as the characteristic low-density, lightcolored wood of the species are important technological requirements for production of particulate wood panels. Given the above, this work aimed to evaluate the quality of particleboard panels manufactured with wood from Sequoia sempervirens combined with wood from Pinus taeda at different ratios.

\section{MATERIALS AND METHODS}

Wood particles from Sequoia sempervirens and Pinus taeda were used to proceed with the experiment. The sequoia particles were obtained from six logs removed from three 18-year-old trees from stands located in EPAGRI Experimental Station, São Joaquim (SC). The pine particles, used in the outer layers of industrial panels, were obtained from the production line of Berneck S.A., a company located in Araucária (PR).

The sequoia particles were obtained in a disc chipper, to a length of $50 \mathrm{~mm}$, a thickness of $0.7 \mathrm{~mm}$ and variable width of $50 \mathrm{~mm}$. Once dried to a moisture content of $3 \%$, the particles were reprocessed in a hammer mill and then graded using a $0.8 \mathrm{~mm}$ mesh sieve to remove fine particles. The particles retained in the sieve were used to manufacture the panels.

Fifteen panels were made measuring $500 \mathrm{~mm}$ in width and in length and $15 \mathrm{~mm}$ in thickness. The amount of material required to form a mat was determined, considering a panel density of $800 \mathrm{~kg} \cdot \mathrm{m}^{-3}$. The resin used was urea-formaldehyde (UF) at a rate of $10 \%$, on dry particle weight basis, using ammonium sulfate as a catalyst

Cerne, Lavras, v. 20, n. 2, p. 209-216, abr./jun. 2014 
at a rate of $2 \%$ on resin solids. The catalyzed resin and the wax ( $1 \%$ on resin solids) were applied to the particles in a rotary tumbler using an integrated spray nozzle.

The particles were sorted and divided into five different mixing ratios of the two species, according to the treatments provided in Table 1 .

Table 1 - Experimental design.

Tabela 1 - Delineamento experimental.

\begin{tabular}{ccc}
\hline \multirow{2}{*}{ Treatment } & \multicolumn{2}{c}{ Mixing ratios (\%) } \\
\cline { 2 - 3 } & Sequoia sempervirens & Pinus taeda \\
\hline T1-s100p0 & 100 & 0 \\
T2-s0p100 & 0 & 100 \\
T3-s75p25 & 75 & 25 \\
T4-s50p50 & 50 & 50 \\
T5-s25p75 & 25 & 75 \\
\hline
\end{tabular}

After applying wax and resin, the mat of particles was shaped into form inside a molding box and pre-pressed prior to being hot pressed. The panels were then pressed at a temperature of $160^{\circ} \mathrm{C}$, specific pressure of $40 \mathrm{kgf} / \mathrm{cm}^{3}$, for 8 minutes. Three panels were made per treatment, to a total of 15 panels.

After being pressed, the panels were trimmed to size and kept in a temperature-controlled room at $20 \pm 3^{\circ} \mathrm{C}$ with relative humidity of $65 \pm 5 \%$.

To establish the physico-mechanical properties, nine specimens were taken from each panel to determine density and compaction ratio; nine specimens were taken to determine water absorption and thickness swelling after 24 hours of immersion in water; six specimens were subjected to bending tests to determine the modulus of elasticity (MOE) and modulus of rupture (MOR), static by using a universal testing machine and dynamic by applying stress waves; and nine specimens were subjected to internal bond testing. The tests were conducted according to procedures described in Standards EN 323, EN 317, EN 310 and EN 319 (CEN, 1993a, 1993b, 1993c, 1993d) respectively.

The experiment was laid out in a completely randomized design, and the statistical analysis was based on analysis of variance and the Tukey test at the 95\% probability level.

\section{RESULTS AND DISCUSSION}

\subsection{Density and compaction ratio of panels}

Results of wood and panel bulk density and also compaction ratio are illustrated in Table 2. Bulk wood density, as calculated for different mixing ratios of Sequoia sempervirens and Pinus taeda, ranged between $321 \mathrm{~kg} . \mathrm{m}^{-3}$ and $496 \mathrm{~kg} \cdot \mathrm{m}^{-3}$ respectively. Due to the low density which is characteristic of sequoia wood $\left(321 \mathrm{~kg} \cdot \mathrm{m}^{-3}\right)$ compared to the density of pine wood $\left(496 \mathrm{~kg} \cdot \mathrm{m}^{-3}\right)$, increasing the proportion of pine in the mixture by $25 \%$ (T3), $50 \%$ (T4)

Table 2 - Results of density and compaction ratio.

Tabela 2 - Resultados de massa específica e razão de compactação dos painéis.

\begin{tabular}{ccccc}
\hline \multirow{2}{*}{ Treatment } & MEm $\left(\mathrm{kg} \cdot \mathrm{m}^{-3}\right)$ & \multicolumn{2}{c}{ MEp $\left(\mathrm{kg} \cdot \mathrm{m}^{-3}\right)$} & \multirow{2}{*}{ RC } \\
\cline { 3 - 4 } & & Mean & CV $(\%)$ & \\
\hline T1 & 321 & $732 \mathrm{a}$ & 4.0 & $2.279 \mathrm{a}$ \\
T2 & 496 & $719 \mathrm{a}$ & 3.6 & $1.449 \mathrm{~b}$ \\
T3 & 365 & $727 \mathrm{a}$ & 3.3 & $1.993 \mathrm{c}$ \\
T4 & 409 & $734 \mathrm{a}$ & 4.2 & $1.797 \mathrm{~d}$ \\
T5 & 452 & $736 \mathrm{a}$ & 4.9 & $1.628 \mathrm{e}$ \\
\hline
\end{tabular}

MEm: wood bulk density (species in pure state and at different mixing ratios); MEp: panel bulk density; RC: compaction ratio; $\mathrm{CV}$ : coefficient of variation; s: sequoia; $\mathrm{p}$ : pine. Means followed by the same letter in a column do not differ statistically, at the 95\% probability level.

and $75 \%$ (T5) resulted in higher values of density in the material.

Panel bulk density ranged between $719 \mathrm{~kg} \cdot \mathrm{m}^{-3}$ and $736 \mathrm{~kg} . \mathrm{m}^{-3}$ respectively for panels made with $100 \%$ pine and for the mixture of $25 \%$ sequoia and $75 \%$ pine. However, no statistically significant differences were found between treatments. The lower values found for panel density relative to the nominal density of $800 \mathrm{~kg} \cdot \mathrm{m}^{-3}$, as established for calculating the materials, could be attributed to loss of material during the panel forming process and to thickness recovery after the pressing stage.

Compaction ratio ranged between 1.449 (T2) and 2.279 (T1). It was noted that increasing ratios of sequoia wood $(\mathrm{T} 5, \mathrm{~T} 4, \mathrm{~T} 3)$ in relation to pine wood resulted in higher values of compaction ratio. This variation occurs because sequoia wood has lower density.

Cerne, Lavras, v. 20, n. 2, p. 209-216, abr./jun. 2014 
High values of compaction ratio were also found in other studies using low-density wood to make particleboards. Trianoski et al. (2011b) found values above 2 for particleboards made with Schizolobium parahyba $\left(264 \mathrm{~kg} \cdot \mathrm{m}^{-3}\right)$ and Toona ciliata $\left(373 \mathrm{~kg} \cdot \mathrm{m}^{-3}\right)$. Iwakiri et al. (2010) found values above 2 for particleboards made with Schizolobium amazonicum (320 kg.m ${ }^{-3}$ ) and Cecropia hololeuca $\left(270 \mathrm{~kg} \cdot \mathrm{m}^{-3}\right)$.

\subsection{Water absorption and thickness swelling}

Mean results of water absorption and thickness swelling after 24 hours of immersion in water are illustrated in Table 3. Panels made with $100 \%$ sequoia (T1) and with sequoia in a mixture with pine at $75 \%$ (T3), $50 \%$ (T4) and $25 \%$ (T5) had mean values of water absorption statistically lower than panels made with $100 \%$ pine (T2). Panels made

Table 3 - Results of water absorption and thickness swelling.

Tabela 3 - Resultados de absorção de água e inchamento em espessura.

\begin{tabular}{ccccc}
\hline \multirow{2}{*}{ Treatment } & \multicolumn{2}{c}{ Water absorption } & \multicolumn{2}{c}{ Thickness swelling } \\
\cline { 2 - 5 } & Mean (\%) & CV (\%) & Mean (\%) & CV (\%) \\
\hline T1 & $42.9 \mathrm{~b}$ & 11.5 & $16.3 \mathrm{~b}$ & 27.7 \\
T2 & $55.4 \mathrm{a}$ & 12.8 & $22.2 \mathrm{a}$ & 16.3 \\
T3 & $45.4 \mathrm{~b}$ & 11.2 & $13.9 \mathrm{c}$ & 24.4 \\
T4 & $26.3 \mathrm{~d}$ & 13.3 & $8.3 \mathrm{~d}$ & 11.3 \\
T5 & $34.2 \mathrm{c}$ & 8.1 & $10.6 \mathrm{~d}$ & 11.8
\end{tabular}

Means followed by the same letter do not differ statistically at the 95\% probability level. CV: Coefficient of variation.

with $50 \%$ and $25 \%$ sequoia in the mixture had the lowest values of water absorption.

Results of thickness swelling after 24 hours revealed the same trend as water absorption. Panels made with $100 \%$ pine (T2) had a mean value of thickness swelling statistically higher than panels made with $100 \%$ sequoia (T1) or with three different mixing ratios of pine. Panels made with $50 \%$ and $25 \%$ sequoia had lower values of thickness swelling.

Compaction ratio was found to influence the physical properties of the panels but only in results of water absorption, in accordance with which the panels with higher compaction ratio had lower values of water absorption. According to Moslemi (1974), panels with a higher compaction ratio have a more closed structure which contributes to obstruct the entry of water. As for thickness swelling, compaction ratio was found not to influence results.

Mean results of water absorption and thickness swelling for panels made with $100 \%$ sequoia and with a mixture of sequoia and pine at different ratios were lower compared to some results in literature. Iwakiri et al. (2010) found, for panels made with paricá and embaúba woods at the ratios $0 \%, 25 \%, 50 \%, 75 \%$ and $100 \%$, mean values of water absorption and thickness swelling in the range of $80.57 \%$ to $79.22 \%$ and $28.42 \%$ to $26.19 \%$ respectively. In another study, Iwakiri et al. (1996) found, for panels made with a mixture of Pinus taeda and Eucalyptus dunnii at the ratios $0 \%, 25 \%, 50 \%, 75 \%$ and $100 \%$, values of water absorption in the range of $75.04 \%$ to $80.05 \%$ and thickness swelling in the range of $30.19 \%$ to $35.09 \%$ respectively. The panels made with mixed sequoia and pine at the ratios $25 \%, 50 \%$ and $75 \%$ were found to meet the requirement of standard EN 312 (EUROPEAN COMMITTEE FOR STANDARDIZATION - CEN, 2003) concerning thickness swelling after 24 hours of immersion in water, whose maximum value is $15 \%$.

\subsection{Static bending}

Results of modulus of elasticity (MOE) and modulus of rupture (MOR) are given in Table 4. Panels made with $100 \%$ sequoia had a mean MOE statistically similar to panels made with $100 \%$ pine or with a mixture of the two species at three different ratios (T3, T4, T5). Panels made with a mixture of sequoia and pine at three

Table 4 - Results of modulus of elasticity and modulus of rupture in static bending.

Tabela 4 - Resultados de módulo de elasticidade e de ruptura em flexão estática.

\begin{tabular}{ccccc}
\hline \multirow{2}{*}{ Treatment } & \multicolumn{2}{c}{ MOE $(\mathrm{MPa})$} & \multicolumn{2}{c}{ MOR (MPa) } \\
\cline { 2 - 5 } & Mean & CV $(\%)$ & Mean & CV (\%) \\
\hline T1 & $2,126 \mathrm{ab}$ & 24.4 & $17.76 \mathrm{a}$ & 18.78 \\
T2 & $1,847 \mathrm{~b}$ & 14.93 & $12.78 \mathrm{~b}$ & 15.90 \\
T3 & $2,319 \mathrm{a}$ & 17.66 & $17.93 \mathrm{a}$ & 15.91 \\
T4 & $2,481 \mathrm{a}$ & 18.05 & $18.96 \mathrm{a}$ & 15.29 \\
T5 & $2,351 \mathrm{a}$ & 16.38 & $18.13 \mathrm{a}$ & 16.59 \\
\hline
\end{tabular}

MOE: modulus of elasticity; MOR: modulus of rupture; CV: coefficient of variation; s: sequoia; p: pine. Means followed by the same letter in a column do not differ statistically at the $95 \%$ probability level. 
different ratios resulted in statistically higher values of MOE compared to panels made with $100 \%$ pine.

As regards MOR, panels made with $100 \%$ pine had statistically lower mean values than panels made with $100 \%$ sequoia or with a mixture of the two species at three different ratios (T3, T4, T5).

Increased values of MOE and MOR in panels made with $100 \%$ sequoia or with a mixture of sequoia and pine may be associated with the increase in the compaction ratio of the panels by including sequoia wood, whose density is lower than that of pine wood. A direct correlation between the compaction ratio and the mechanical properties of particleboard panels is also reported by Maloney (1993) and Moslemi (1974).

Comparatively, Trianoski et al. (2011b) found 2,247 and 16.36 MPa, 2,405 and 16.93 MPa, 1,878 and $10.87 \mathrm{MPa}, 2,137$ and $16.38 \mathrm{MPa}, 2,529$ and $18.73 \mathrm{MPa}$ as mean values of MOE and MOR respectively for threeply particleboard panels manufactured using Acrocarpus fraxinifolius, Melia azedarach, Gravilea robusta, Schizolobium parahyba and Toona ciliata in the outer layers and Pinus taeda in the inner layer. In another study, Trianoski et al. (2011a) found 1,948 and $12.88 \mathrm{MPa}, 1,861$ and 13.09 MPa, 2,312 and 16.64 MPa, 1,917 and 13.63 $\mathrm{MPa}, 1,742$ and $11.82 \mathrm{MPa}$ as mean values of MOE and MOR respectively for panels made with a mixture of Pinus taeda and Acrocarpus fraxinifolius at the ratios $100 \%$ pine, $100 \%$ acrocarpus, and $75 \%, 50 \%$ and $25 \%$ acrocarpus to pine. Therefore, the results of MOE and MOR obtained in this study are consistent with values reported in literature. The results of MOE and MOR for all treatments were found to be above the minimum requirements of standard EN 312 (CEN, 2003), which are respectively 1,600 MPa and $13 \mathrm{MPa}$.

Table 5 and Figure 1 provide mean values of static MOE and dynamic MOE and their correlations.

No significant differences were found between

Table 5 - Mean values of MOE static and MOE dynamic.

Tabela 5 - Valores médios de MOE estático e MOE dinâmico.

\begin{tabular}{cccc}
\hline Treatment & $\mathrm{MOE}_{\text {est }}(\mathrm{MPa})$ & $\mathrm{MOE}_{\text {din }}(\mathrm{MPa})$ & $\mathrm{MOE}_{\text {din }} / \mathrm{MOE}_{\text {est }}$ \\
\hline T1-s100p0 & $2,126 \mathrm{ab}$ & $1,847 \mathrm{~b}$ & 0.869 \\
$\mathrm{~T} 2-\mathrm{s} 0 \mathrm{p} 100$ & $1,847 \mathrm{~b}$ & $2,066 \mathrm{ab}$ & 1.118 \\
T3-s75p25 & $2,319 \mathrm{a}$ & $2,121 \mathrm{ab}$ & 0.915 \\
T4-s50p50 & $2,481 \mathrm{a}$ & $2,119 \mathrm{ab}$ & 0.854 \\
T5-s25p75 & $2,351 \mathrm{a}$ & $2,027 \mathrm{ab}$ & 0.862 \\
\hline
\end{tabular}

Means followed by the same letter in a column do not differ statistically at the $95 \%$ probability level. the mean values of dynamic MOE for all treatments. The correlations between static MOE and dynamic MOE were less than 1 , except for $\mathrm{T} 2$, indicating that the mean values of dynamic MOE were below those found for static MOE.

The graphs drawn reveal a high correlation between static MOE and dynamic MOE for all treatments. The correlation coefficient (R2) ranged between $77 \%$ and $87 \%$, and the highest correlation was found for treatment T1. Ross and Pellerin (1988) reported a high correlation between static MOE and dynamic MOE properties for particleboard panels.

\subsection{Internal bond}

Table 6 provides results of internal bond. Panels made with a mixture of pine and sequoia particles at three different ratios (T3, T4, T5) had statistically higher mean values of internal bond compared to panels made with $100 \%$ pine or $100 \%$ sequoia. These results are of great importance as indicative of the feasibility of using mixed sequoia and pine to manufacture superior quality particleboards. The results also point to the possibility of mixing up to $75 \%$ sequoia with pine wood to manufacture particleboards. As observed for MOE and MOR, the higher compaction ratio found in panels made with sequoia at different ratios did contribute to increase the values of internal bond.

The mean results of internal bond between 0.702 and $0.894 \mathrm{MPa}$, as obtained for panels made with $100 \%$ sequoia and with different mixing ratios, did meet the minimum requirement established by European Standard EN 312 (CEN, 2003), which is $0.35 \mathrm{MPa}$.

Comparatively to values reported in literature, Iwakiri et al. (2010) found 0.76 and $0.68 \mathrm{MPa}$ of internal bond when studying particleboards made with Schizolobium amazonicum (paricá) and Cecropia hololeuca (embaúba) respectively. Therefore, the results found for panels made

Table 6 - Results of internal Bond.

Tabela 6 - Resultados de ligação interna.

\begin{tabular}{ccc}
\hline Treatment & \multicolumn{2}{c}{ Internal bond $(\mathrm{MPa})$} \\
\hline & Mean & $\mathrm{CV}(\%)$ \\
T1 & $0.702 \mathrm{a}$ & 26.5 \\
T2 & $0.583 \mathrm{a}$ & 17.9 \\
T3 & $0.875 \mathrm{~b}$ & 23.7 \\
T4 & $0.894 \mathrm{~b}$ & 18.7 \\
T5 & $0.859 \mathrm{~b}$ & 26.2 \\
\hline
\end{tabular}

CV: Coefficient of variation; Means followed by the same letter in a column do not differ statistically at the $95 \%$ probability level.

Cerne, Lavras, v. 20, n. 2, p. 209-216, abr./jun. 2014 
Treatment 1

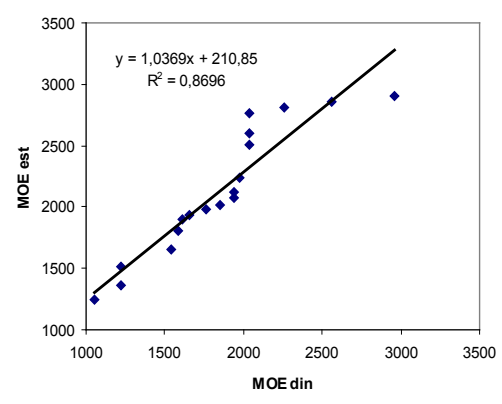

Treatment 2

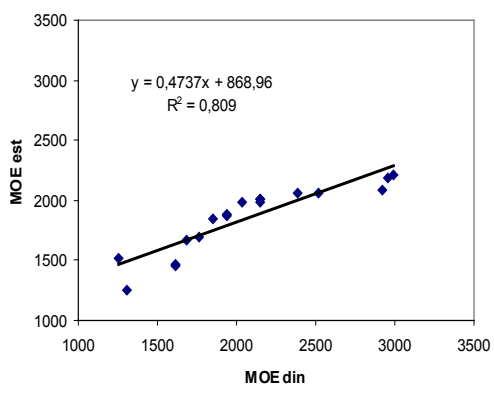

Treatment 3

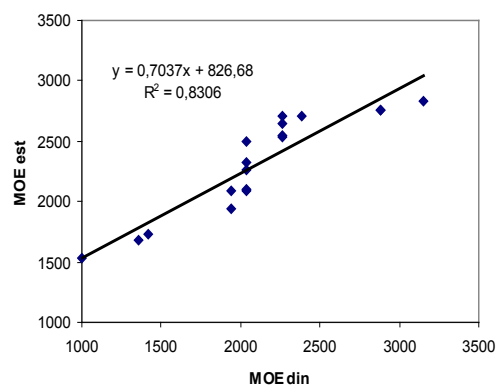

Treatment 4

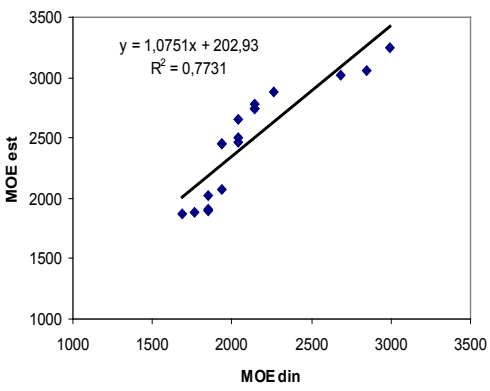

Treatment 5

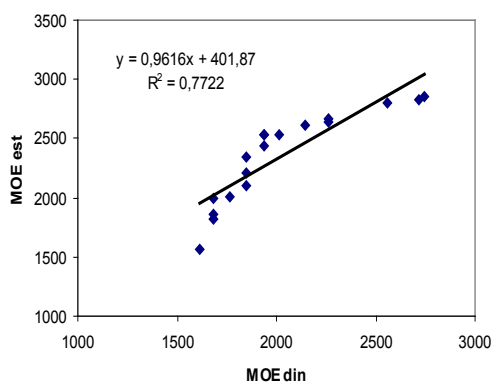

Figure 1 - Graphic of linear correlation between static and dynamic MOE.

Figura 1 - Gráfico de correlação linear entre o MOE estático e dinâmico.

\section{CONCLUSION}

Based on the results found in this study, the following conclusions can be drawn:

- The low density of sequoia wood and the consequent increase in compaction ratio were found to influence the increase in the mechanical properties and the reduction in the physical properties of the resulting panels.

- Panels made with Sequoia sempervirens provided better results of physical and mechanical properties compared to panels made with Pinus taeda, which is a species traditionally used by manufacturers of particleboard panels.

- Results of static bending, internal bond, water absorption and thickness swelling tests were satisfactory in relation to reference values reported in literature for fast-growing wood species cultivated in forest stands.

- Results of MOE and MOR under static bending and internal bond of panels were found to meet the minimum requirements of standard EN 312 (CEN, 2003) in all treatments. With respect to thickness swelling after
24 hours, only the panels made with a mixture of the two species at the ratios $25 \%, 50 \%$ and $75 \%$ were found to meet the requirements of said standard.

\section{REFERENCES}

\section{ASSOCIAÇÃO BRASILEIRA DA INDÚSTRIA DE PAINÉIS DE MADEIRA. ABIPA: [home page].}

Disponível em: <http:// www.abipa.org.br/>. Acesso em: 25 mar. 2012.

\section{EUROPEAN COMMITTEE FOR}

STANDARDIZATION (CEN). EN 310. Wood-based panels - Determination of modulus of elasticity and modulus of rupture in static bending. 1993.

EUROPEAN COMMITTEE FOR STANDARDIZATION (CEN). EN 312. Particleboards - Specifications. 2003

EUROPEAN COMMITTEE FOR STANDARDIZATION (CEN). EN 317. Aglomerado de

Cerne, Lavras, v. 20, n. 2, p. 209-216, abr./jun. 2014 
partículas de madeira e aglomerado de fibras de madeira - Determinação da absorção de água e inchamento em espessura após imersão em água. 1993.

\section{EUROPEAN COMMITTEE FOR}

STANDARDIZATION (CEN). EN 319. Aglomerado de partículas de madeira e aglomerado de fibras de madeira - determinação da força da tensão perpendicular sobre a superfície plana da placa. 1993.

\section{EUROPEAN COMMITTEE FOR}

STANDARDIZATION (CEN). EN 323. Wood-based panels - Determination of density. 1993.

IWAKIRI, S.; LATORRACA, J.V.F.; SILVA, D.A.; GABARDO, J.L.; KLITZKE, R.J.; FOFANO, A.; FABROWSKI, F.; INTERANMENSE, M.T. Produção de painéis aglomerados de Pinus elliottii e Eucalyptus dunnii. Agrárias, Curitiba, v. 15, n. 1, p. 33-41, 1996.

IWAKIRI, S.; ZELLER, F. PINTO, J. A.; RAMIREZ, M. G. L.; SOUZA, M. M.; SEIXAS, R. Avaliação do potencial de utilização da madeira de Schizolobium amazonicum "Paricá" e Cecropia hololeuca "Embaúba" para produção de painéis aglomerados. Acta

Amazonica, Manaus, v. 40, n. 2, p. 303-308, 2010.

IWAKIRI, S.; SILVA, J.R.M.; MATOSKI, S.L.S.; LEONHARDT, G.; CARON, J. Produção de chapas de madeira aglomerada de cnco espécies de pinus tropicais. Floresta e Ambiente, Seropédica, v. 8, n. 1, p. 137-142, 2012.

KELLY, M. W. A critical literature review of relationship between processing parameters and physical properties of particlebard. Madison: U.S. For. Prod. Lab. General Technical Report, 1977. 66p.

MALONEY, T. M. Modern particleboard and dryprocess fiberboard manufacturing. São Francisco: Miller Freeman, 1993. 689p.

MARCHIORI, J.N.C. Dendrologia das Gimnospermas. Ed. UFSM, 1996 citado por DIEL J. e FIZZO, S. Estudos de caracterização da Sequoia sempervirens para produção de celulose Kraft. In: 35o Congresso e exposição anual de celulose e papel. Anais... São Paulo, 2002.

MOSLEMI, A. A. Particleboard Vol. 1: Materials. Londres: Southerns Illinois University Press, 1974. $244 p$.
PROTÁSIO, T.P.; GUIMARÃES Jr, J.B.; MENDES, R.F.; MENDES, L.M.; GUIMARÃES, B.M.R. Correlações entre as propriedades físicas e mecânicas de painéis aglomerados de diferentes espécies de Eucalyptus. Floresta e Ambiente, Seropédica, v. 19, n. 2, p. 123-132, 2012.

ROSS, R. J; PELLERIN, R. F. NDE of wood-based composites with longitudinal stress waves. Forest Products Journal, Washington, v. 38, n. 5. P. 39 - 45, 1988.

SLOAN, J.; BOE, K. Sequoia sempervirens (Lamb. Ex D. Don) Endl. Seeds of Woody plants in the United States. Schopmeyer: USDA, 1974.

SPICHINGER, O. A. Aprovechamiento en el aserrado de sequoia (Sequoia sempervirens (D.DON) Endl.) y clasificación de La madera obtenida. 2004. 61 p. Dissertação (Mestrado em Ingeniería de La madeira) Universidad de Chile, Santiago.

TRIANOSKI, R.; IWAKIR, S.; MATOS, J.L.M.; PRATA, J.G. Avaliação de espécies alternativas de rápido crescimento para produção de painéis de madeira aglomerada de três camadas. Scientia Forestalis, Piracicaba, v. 39, n. 89, p. 097-104, 2011a.

TRIANOSKI, R.; IWAKIR, S.; MATOS, J.L.M.; PRATA, J.G. Viabilidade da utilização de Acrocarpus fraxinifolius em diferentes proporções com Pinus spp. para produção de painéis aglomerados. Scientia Forestalis, Piracicaba, v. 39, n. 91, p. 343-350, 2011 b.

Received: May 02, 2012; accepted: August 23, 2013.

Cerne, Lavras, v. 20, n. 2, p. 209-216, abr./jun. 2014 
